\title{
ЖИТТСВИЙ ЦИКЛ ОРГАНІЗАЦІЇ СИСТЕМИ ТРИВОЖНОЇ СИГНАЛІЗАЦІї
}

\author{
Шишак А. В. ${ }^{1}$, Пупена О. М. ${ }^{2}$ \\ ${ }^{1,2}$ Національний університет харчових технологій, Київ, Україна \\ ORCID: ${ }^{1}$ https://orcid.org/0000-0001-9860-7430, ${ }^{2}$ https://orcid.org/0000-0001-9089-8325 \\ E-mail: ${ }^{1}$ al_sh_94@ukr.net, ${ }^{2}$ pupena_san@ukr.net
}

Copyright (C) 2021 by author and the journal “Automation of technological and business - processes”. This work is licensed under the Creative Commons Attribution International License (CC BY). http://creativecommons.org/licanses/by/4.0

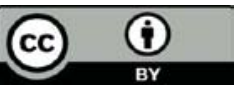

\section{ONAFT}

Open Access

\section{DOI:}

\begin{abstract}
Анотація. Автоматизована система керування технологічним процесом передбачає наявність функиій тривожної сигналізації, які виконують надзвичайно важливу роль. Від ефективності роботи підсистеми тривожної сигналізації залежить передусім безпека людей, виробництва та функиіонування автоматизованої системи керування технологічним процесом в ціілому. В Україні розробленню, впровадженню та експлуатації систем тривожної сигналізації приділяється недостатньо уваги. Тому ие дослідження присвячено передусім трактуванню сучасного стандарту ISA-18.2 «Management of Alarm Systems for the Process Industries», який є визнаною хорошою інженерною практикою та покликаний забезпечити безпеку, якість та продуктивність технологічних процесів. Даній тематиці присвячено дві публікації. У пермій вже опублікованій статті розкриваються основні сутності та положення, на яких базуються механізми організації системи тривожної сигналізації. Ця стаття присвячена роз'ясненню та аналізу робочих прочесів життєвого циклу організації, які стандарт передбачає для розроблення, впровадження та експлуатації системи тривожної сигналізації. Організаџія функціонування системи тривожноі сигналізації - ие неперервна діяльність, усі робочі процеси якої розділені на десять стадій життєвого цฺиклу, щзо вказують на функиіональний аспект робіт, обов'язкових або рекомендованих до виконання. До них належать означення, документування, проектування, експлуатація, моніторинг та обслуговування систем тривожної сигналізації. Представлення системи через призму життєвого ичилу організації ї̈ роботи дозволяє систематизувати уявлення розробників/користувачів про прочеси, які відбуваються навколо системи за рахунок стадійного структурування вимог та рекомендащій.

Abstract. The automated process control system provides alarm functions, which play an extremely important role. The safety of people, production and operation of the automated process control system in general depends on the efficiency of the alarm subsystem. In Ukraine, insufficient attention is paid to the development, implementation and operation of alarm systems. Therefore, this study is primarily devoted to the interpretation of the modern standard ISA-18.2 "Management of Alarm Systems for the Process Industries", which is a recognized good engineering practice and is designed to ensure the safety, quality and performance of technological processes. Two publications are devoted to this topic. The first already published article reveals the main entities and principles on which the mechanisms of alarm system management are based. This article is devoted to the explanation and analysis of the work processes of the management life cycle, which the standard provides for the development, implementation and operation of an alarm system. The alarm system management is a continuous activity, all work processes of which are divided into ten stages of the life cycle, indicating the functional aspect of the work required or recommended. These include the definition, documentation, design, operation, monitoring and maintenance of alarm systems. Representation of the system through the prism of the management life cycle allows to systematize the ideas of developers/users about the processes that take place around the system through the stage structuring of requirements and recommendations.
\end{abstract}

Ключові слова: система тривожної сигналізації, тривога, SCADA, HMI, ISA-18.2, життєвий цикл.

Keywords: alarm system, alarm, SCADA, HMI, ISA-18.2, lifecycle.

Вступ.

До широкого впровадження цифрових систем технологічний процес відображувався на величезній стіні, яка була нагромаджена різноманітними індикаторами, лампочками, перемикачами та різного типу самописцями. Звичайно, всі ці пристрої займали занадто багато простору на АРМ оператора. Взагалі використання такої мнемосхеми мало свої позитивні сторони. В ході їі розроблення задачі розміщення та групування приділялося дуже багато уваги. Тому 
загальний стан процесу оцінювався з одного погляду. Під час аварійних ситуацій індикатори та лампочки сигналізації утворювали повторювані шаблони, а тренди завжди були перед очима поки папір і чорнила в наявності.

Це все було до цифрової революції та проривного впровадження сучасних засобів керування, таких як системи DCS та SCADA. Новий підхід приніс величезні переваги для бізнесу. Поведінка системи змінювалася програмно без особливих проблем. Проте стаття присвячена системам тривожної сигналізації (далі СТС), тому слід звернути увагу на те, як впровадження цифрових систем вплинуло на безпеку процесу. 3 моменту появлення можливості відображати тривоги у вигляді «нескінченного» списку на екрані монітора або ж за допомогою різноманітного набору графічних елементів, інженери стали дуже креативними. Якщо система надавала можливість налаштувати критичну тривогу, критично-критичну та навіть критично-критично-критичну для всіляких потенційних тривог, чому б і ні. Для цього потрібно було зробити лише кілька кліків. У зв’язку з тим, що у розробників не було ніяких керівництв по створенню тривог, історія наповнюється поганими прикладами реалізації підсистем тривог серед яких використання тривог за замовчуванням, налаштування за непослідовними правилами або означення за індивідуальними уподобаннями.

Як результат - тривоги активуються дуже часто, генеруючи при цьому стільки повідомлень, що оператор не встигає їх проаналізувати та відреагувати належним чином. В аварійній ситуації потік тривог руйнує усю цінність системи сигналізації. Відповідно до результатів розслідувань великих виробничих аварій, істотну роль у погіршенні аварійної ситуації відігравали проігноровані тривоги. Проте такі інциденти - це лише верхівка айсберга. Тому що звичні порушення процесу, пов'язані з неефективним функціонуванням системи сигналізації, можуть завдавати великої шкоди, що відповідно призводить до значних витрат.

Прогалина у роботі систем тривожної сигналізації набула розголосу на початку 1990 саме завдяки звітам 3 розслідувань аварій. Як підтвердження того наводимо уривок зі звіту, сформованого управлінням по охороні праці у Великій Британії після розслідування великого виробничого інциденту[1]:

- Було забагато погано пріоритизованих тривог.

- Дисплеї процесів (мнемосхеми) не допомогли операторам зрозуміти, щзо відбувалося.

- За останні 11 хвилин до вибуху обом операторам довелося реагувати на 275 тривог.

Завдяки усвідомленню того, що неефективна робота СТС займала серйозне місце серед причин виникнення великих виробничих аварій, в 1994 році було сформовано консорціум Управління позаштатними ситуаціями (від англ. the Abnormal Situation Management Consortium). Організація досі займається дослідженнями, розробкою інструментів, кращих практик та послуг з метою успішного зменшення позаштатних ситуацій у хімічних процесах [2].

В 1999 році Асоціацією користувачів інженерного обладнання та матеріалів (від англ. the Engineering Equipment and Materials Users Association) було опубліковано керівництво щодо проектування, управління та закупівлі ефективної системи тривожної сигналізації. Наразі актуальним є третє видання 2013 EEMUA Publication 191 Alarm systems - a guide to design, management and procurement [3].

Асоціація користувачів технологій автоматизації в переробних галузях (від нім. Interessengemeinschaft Automatisierungstechnik der Prozessindustrie) в 2003 році видала рекомендації до розроблення CTC NA 102, Alarm Management.

У 2003 році ISA розпочала розроблення стандарту присвяченого організації функціонування систем тривожної сигналізації. Десятки учасників (включаючи авторів) з багатьох галузей промисловості витратили тисячі годин на написання документу, в ході чого було докладено всіх зусиль, щоб термінологія та методологія відповідали попереднім роботам, які перераховані вище. Після 6 років роботи, в 2009 році була видана перша редакція «ANSI/ISA-18.2-2009, Management of Alarm Systems for the Process Industries» [4].

В 2014 році МЕК адаптував ISA 18.2 та видав IEC 62682:2014. Враховуючи доповнення мековського видання, організація ISA перевидала стандарт 2016 року. Беручи до уваги вище сказане, ISA 18.2 є узагальнюючим документом, який містить у собі переосмисленні знання та напрацювання багатьох організацій протягом більше 20-ти років. Попередня стаття авторів про ISA 18.2 [5] присвячена основним поняттям стандарту. Дана стаття зосереджується на процесах життєвого циклу системи тривожної сигналізації, через призму якого описані практики, які вказують на функціональний аспект робіт, обов’язкові або рекомендовані до виконання для ефективного функціонування СТС. Окрім цього українським виданням в 2020 році було опубліковано навчальний посібник «Розроблення людино-машинних інтерфейсів та систем збирання даних 3 використанням програмних засобів SCADA/HMI» [6], в якому цілий роздій присвячено розробленню підсистем тривожної сигналізації.

\section{Мета дослідження.}

Враховуючи, що стандарт повинен мати силу у спільноті автоматників з метою покращення безпеки технологічних процесів, якості продукції та продуктивності виробництва, метою дослідження є освітлення основних діяльностей необхідних для побудови безпечних, надійних і ефективних систем керування. Життєвий цикл організації систем тривожної сигналізації сильно впливає на їі ефективність, тому автори вирішили зробити аналіз моделі життєвого циклу СТC, викладеного в ISA-18.2.

\section{Матеріали та результати дослідження.}

Існує декілька хибних думок щодо будь-яких стандартів. Вони не являються керівництвом, вони зосереджуються на тому що робити, а не як це робити. Те саме стосується і ISA-18.2. Тут не написано крок за кроком, як розробити найефективнішу СТС. В стандарті наводяться опис робочих процесів, вимоги та рекомендації до них. Усі процеси 
організації функціонування СТС розділені на 10 стадій життєвого циклу за функціональним призначенням. До них належать означення, документування, проектування, експлуатація, моніторинг та обслуговування систем тривожної сигналізації.

На рисунку 1 показаний взаємозв'язок між стадіями життєвого циклу організації систем тривожної сигналізації (далі ОСТС), описаних у стандарті. Життєвий цикл ОСТС охоплює наступні стадії:

- А - методологія (Alarm Philosophy)

- В - ідентифікація (Identification)

- C -раціоналізація (Rationalization)

- D - робоче проектування (Detailed Design)

- Е - впровадження (Implementation)

- F - експлуатація (Operation)

- $\mathrm{G}$ - обслуговування (Maintenance)

- $\mathrm{H}$ - моніторинг і оцінювання (Monitoring and Assessment)

- I - керування змінами (Management of Change)

- $\mathrm{J}$ - Аудит (Audit)

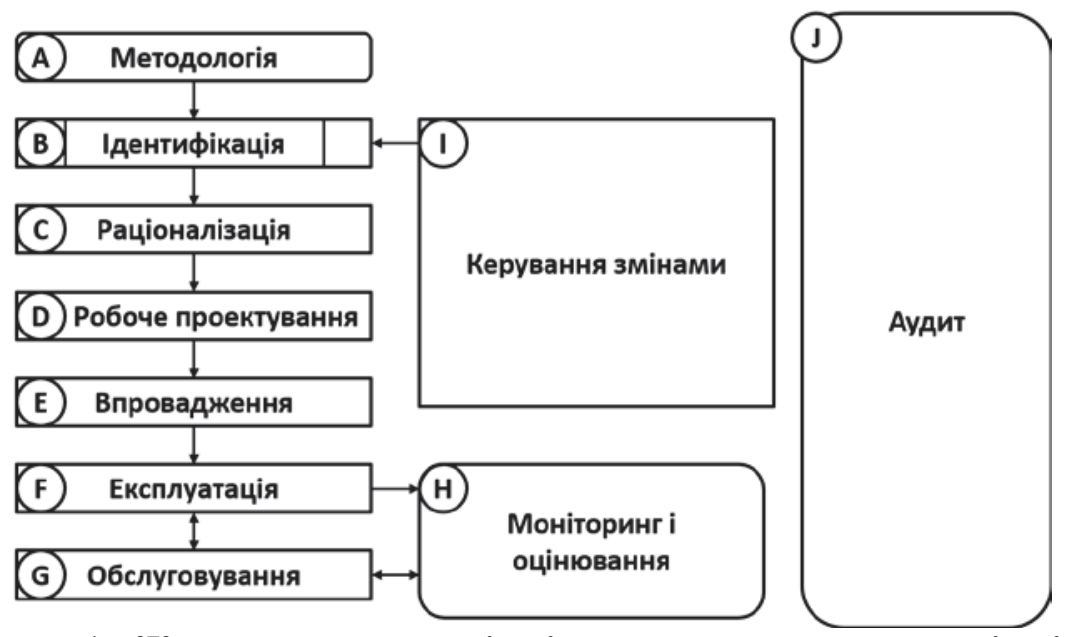

Рисунок 1 - Життєвий цикл організації системи тривожної сигналізації

Звертаємо увагу читача на те, що необхідно правильно розуміти метод викладення вимог та рекомендацій у стандарті. Життєвий цикл - це спосіб структурування змісту усього стандарту ISA-18.2. Таке подання опису робочих процесів не є списком робіт, які необхідно провести у визначеному порядку.

У посібнику [1] добре описані міркування інженера, які змальовують ситуацію, яка допоможе правильно сприймати стадії життєвого циклу, описаного у стандарті ISA-18.2: За лічені хвилини інженер міг би сісти і вирішити недолік роботи СТС, який проявляється в наявності однієї хибної вібруючої тривоги. Така задача могла б включати проходження крізь кілька різних стадій життєвого ичиклу як частини виконання діяльностей щуодо вирішення простої задачі. Давайте розглянемо міркування інженера щзодо вирішення проблеми наявності однієї хибної тривоги:

Стадія моніторингу: «Ну добре, виділю собі трохи часу на визначення хибних тривог. Які тривоги найчастіше зустрічаються у списку тривог? С одна така, тривога високого тиску у колоні.»

Стадія Ідентифікації: "Я пам'ятаю, щчо нам потрібна ия тривога відповідно до вимог до якості продукиії; проте моя задача на сьогодні зробити так щзоб вона праџювала правильно, а не вирішити чи взагалі потрібна нам ия тривога чи ні.»

Стадія проектування: «Перевірю налаштування иієї тривоги. Немає нічого незвичного. Я бачу, щцо зона нечутливості для тривоги дорівнює О. Це точно неправильно і спричинює таку «вібруючу» поведінку тривоги. Передивлюся історію тривог і визначу найбільи підходящу зону нечутливості, користуючись довідником.»

Стадія експлуатації і обслуговування: «Зараз я збираюся змінити налаштування зони нечутливості. Чи потрібно мені вивести з експлуатації тривогу і повідомити про цее оператора. Для цієї SCADА системи цуе можна зробити на льоту. І тривога залитатиметься онлайн.»

Стадія керування змінами: «Поки щуо я нічого не змінив. Перед тим як я внесу зміни у налаштування зони нечутливості, я перегляну вимоги щзодо керування змінами. Такий тип змін передбачений документом методології тривог і я маю повноваження внести такі зміни. Мені непотрібна згода інших уповноважених та якісь підписи. Однак мені потрібно буде внести відповідний запис у головну базу даних тривог.»

Стадія впровадження: «Зараз я фактично змінюю зону нечутливості. Увожу нове значення та натискаю 'ENTER'. Зроблено!»

Стадія раціоналізації: «Оскільки у мене є належний доступ до безпеки, я додаю цю нову настройку зони нечутливості до головної бази даних тривог, вказавии своє ім'я, дату та причину. Крім того, я зроблю примітку у щзотижневому звіті по відстеженню хибних тривог. Поки я тут і дивлюся на иңю тривогу, то зауважу, щзо вона 
налаштована з пріоритетом 3. Це здається розумним, але про всяк випадок перевірю головну базу даних тривог, щзоб переглянути причини встановлення такого пріоритету. Це виглядає досить логічно. Якби изого не було, я б не міг самостійно змінити пріоритет. Мені потрібні спеціалісти, які займаються пріоритизацією. Операторів необхідно повідомляти про будь-які зміни пріоритету.»

Стадія моніторингу: "До моӥх обов'язків входить слідкувати за даними тривоги, і переконатися в тому щьо зміна зони нечутливості була рішенням проблеми виникнення хибної тривоги.»

За кілька хвилин виконалось кілька стадій життєвого ичиклу для вирішення однієї задачі.

Для розуміння та застосування ISA-18.2, не потрібно намагатися з'ясувати, на якому етапі життєвого циклу ви перебуваєте в будь-який момент часу. Це структура вимог, а не визначена послідовність робочих процесів. Даний життєвий цикл можна застосовувати для впровадження нових систем тривожної сигналізації або вдосконалення існуючих.

Стадія методології передбачає написання документу методології тривог (далі ДМТ), який розробляється 3 метою забезпечення злагодженої організації СТС по всьому життєвому циклу системи тривожної сигналізації, за рахунок опису робочих процесів усіх стадій. Він починається з основних означень і розширює іх до потрібних функцій. Важливо, щоб у документі методології тривог були означені операційні цілі та показано, за рахунок яких особливостей системи тривожної сигналізації досягаються ці цілі. Потрібно описувати автомат станів, який буде використовуватися в системі тривожної сигналізації. На основі завдань, означень і принципів означаються необхідні пріоритети тривог, класи, показники ефективності, граничні показники ефективності та вимоги до звітності. Означуються не тільки переліки, кількість, назви (високий, середній, низький пріоритети), але і вимоги щодо відношення тривоги до того чи іншого класу, пріоритету і т.п. У цьому документі також оговорюються схеми індикації тривог за допомогою людино-машинного інтерфейсу, які включають і використання пріоритетів.

Організація системи тривожної сигналізації - це мультидисциплінарна та неперервна діяльність. Для забезпечення оптимального функціонування системи неможливо обійтися без підтримки з боку персоналу експлуатації, технічного обслуговування, розробників. Тому важливо в документі методології тривог означувати ролі та відповідальності залученого персоналу, щоб кожен був обізнаний про діяльності, які закріплені за конкретною кадровою групою. Документування розроблення, а також визначення поточних показників функціонування системи може бути важливими для задоволення зовнішніх нормативних вимог або внутрішніх вимог організації. Документ методології тривог для конкретного об'єкта повинен чітко означувати вимоги до документації, включаючи терміни зберігання, обслуговування, рівні доступу та контроль змін, пов'язані з документацією.

Стадія ідентифікації є етапом збору інформації для визначення потенційних тривог та складання їх переліку. Методи визначення потенційних тривог виходять за рамки стандарту, до них належать "process hazards analysis», «safety requirements specifications», «recommendations from an incident investigation», «good manufacturing practice», «environmental permits», «P\&ID development or operating procedure reviews». Процес встановлення потенційних ненормальних умов потребує розгляду з точки зору наступних діяльностей:

- Забезпечення безпеки технологічного процесу (Process safety management, PSM): до типових видів діяльностей регламенту PSM належать: аналіз небезпек технологічного процесу (Process Hazards Analysis, PHA), встановлення безпечних експлуатаційних лімітів процесу передбачених регламентом, ідентифікація механічної надійності устатковання з метою його захисту.

- Екологічні дозволи можуть використовуватися для ідентифікації тривог, які сповіщають оператора про наближення або перевищення допустимих меж екологічно важливих параметрів.

- Звіти 3 розслідування виробничих аварій можуть рекомендувати додавати або змінювати тривоги, щоб запобігти повторному виникненню інциденту. При цьому потрібно враховувати, що рекомендацією в звіті може бути впровадження додаткових тривог, навіть, у випадках, коли саме потік тривог був наведений як одна 3 причин виникнення інциденту.

- Якість: існує кілька національних та міжнародних стандартів та правил (наприклад, cGMPs, ISO), які регулюють процеси дотримання якості продукції.

- Цілі системи керування: для вибраних вимірювань технологічних показників можуть бути встановлені тривоги з метою надання конкретних вказівок оператору. Однак не всі вимірювані чи контрольовані змінні потребують тривог.

- Проектна документація: під час періодичних переглядів P\&ID (схем автоматизації) може бути визначено, що для досягнення цілей керування технологічним процесом та якості продукції можуть знадобитися певні тривоги. Тривоги, виявлені під час огляду $\mathrm{P} \& \mathrm{ID}$, як правило, пов'язані з прямими вимірюваннями технологічних параметрів процесу.

Для вже існуючих систем список потенційних тривог повинен включати існуючі тривоги та запропоновані додаткові тривоги. Що стосується нових систем, то список повинні складати потенційні тривоги для нових виробничих майданчиків.

Стадія раціоналізації узгоджує ідентифіковані тривоги чи зміни до системи тривожної сигналізації з принципами, які зазначені у документі методології тривог. Це процес застосування вимог до тривог і формування допоміжної документацій, до якої включаються уставки тривог, наслідки, умови спрацювання тривог та необхідні дії оператора у відповідь на тривоги. Особлива увага під час стадії раціоналізації приділяється процесам пріоритезації та класифікації 
тривог на основі методів, означених в документі методології тривог. Пріоритет тривоги допомагає оператору у виборі порядку реагування на тривогу в ситуації з декількома тривогами. Для означення пріоритетів тривог зазвичай використовують такі методи:

• метод, який спирається на допустимий час реагування на тривогу оператором;

- метод, який спирається на наслідки тривог.

Віднесення тривог до певних класів в загальному полегшує організацію роботи СТС. Класи можуть мати особливі вимоги до тестування, навчання, процесів керування змінами, звітності або надійності. Критерії для кожного класу тривоги повинні бути означені у ДМТ. Кожна тривога повинна бути призначена до одного або більше класів. Класифікація, як правило, грунтується на наслідках тривог, нормативних вимогах, методах ідентифікації чи інших критеріях, означених у ДМТ, таких як:

• регулятивний характер наслідків, такий як порушення екологічних дозволів;

- тривоги, які вимагають періодичного навчання операторів;

- тривоги, що потребують періодичного тестування;

- тривоги, пов'язані з безпекою технологічних процесів;

- тривоги, пов'язані з якістю продукції.

Результати раціоналізації є задокументованими, як правило, в головній базі даних тривог (від aнгл. таster alarm database, MADB) у вигляді затвердженого документу чи файлу, який зберігається (підтримується, супроводжується) протягом всього життєвого циклу системи тривожної сигналізації. Використання головної бази даних тривог (MADB) спрощує відстеження тривог, включаючи їх документацію, обгрунтування та поточний стан. ISA-18.2 означує MADB як список раціоналізованих тривог та пов'язаних з ними атрибутів. MADB зазвичай включає деякі атрибути тривоги, значення яких можуть бути визначені на етапі робочого проектування [7].

На стадії робочого проектування визначаються та проектуються атрибути тривог, спираючись на вимоги, що були визначені під час раціоналізації. $С$ три області проектування тривог: основне проектування тривог, проектування ЛМІ і проектування тривог з використанням прогресивних технік (від англ. advanced alarming techniques). При основному проектування кожної тривоги головним є визначення значень атрибутів, таких як зона нечутливості, час затримки на спрацювання та вимкнення, повідомлення про тривогу. Умовно, ця частина проектування відноситься до серверної частини підсистеми. Проектування ЛМІ включає означення дисплейних сторінок тривог і елементів оповіщення, включаючи спосіб індикації і пріоритети тривог. Умовно, ця частина відноситься до клієнтської частини підсистеми. Тривоги з використанням прогресивних технік $є$ додатковими функціями, що покращують ефективність системи тривожної сигналізації за межами основної розробки тривог та розробки ЛМІ. Такі методи включають станоорієнтовані тривоги та динамічну пріоритизацію.

Для стадії робочого проектування документ методології тривог повинен означувати рекомендовані значення та/або правила визначення зони нечутливості тривог, часу спрацювання та вимкнення тривог (див. таблиця 1).

Таблиця 1 - Рекомендовані значення зони нечутливості та часу затримки на спрацювання та вимкнення тривог

\begin{tabular}{|c|c|c|}
\hline Тип сигналу & $\begin{array}{c}\text { Зона нечутливості (відсоток } \\
\text { робочого діапазону) }\end{array}$ & $\begin{array}{c}\text { Уас затримки на спрацювання } \\
\text { та вимкнення }\end{array}$ \\
\hline Витрата & $5 \%$ & 15 секунд \\
\hline Рівень & $5 \%$ & 60 секунд \\
\hline Тиск & $2 \%$ & 15 секунд \\
\hline Температура & $1 \%$ & 60 секунд \\
\hline
\end{tabular}

Узгоджене використання кольорів, тексту та інших графічних елементів допомагає оператору виявляти активність тривог і визначати порядок реагування. Стандарт ISA-18.2 не вимагає використання конкретних кольорів для відображення станів тривог. Підходи до індикації можуть відрізнятися в залежності від галузі та регіону. Незалежно від обраної кольорової гами, важливо, щоб кольори, які використовуються в СТС, були унікальними (не використовувалися для інших цілей, крім сигналізації), логічними та відображали пріоритет. Для індикації стану тривог окрім кольорів потрібно використовувати символи, додаткові елементи та/або текст, оскільки дальтонізм доволі часто зустрічається. Повідомлення про тривогу - це текст, який зазвичай відображається поряд із сигналом тривоги на дисплеях тривог. Щоб допомогти оператору діагностувати аномалію та сформулювати відповідь, важливо, надати продумані та легко зрозумілі повідомлення. Методологія тривог повинна документувати формат і правила, яких слід дотримуватися для формування ефективних повідомлень про тривоги. В рамках проектування ЛМІ повинні бути реалізовані функції взаємодії оператора із СТС, серед яких:

• чи допустимо підтвердження декількох тривог одночасно;

- які способи фільтрації тривог будуть надані оператору;

- якщо передбачена функція відтермінування тривог, які тривоги можуть бути відтерміновані, порядок відтермінування, кому дозволено блокувати тривоги та максимальний час відтермінування тривог. 
Добре спроектований людино-машинний інтерфейс надає можливість операторам переходити до джерела тривоги кількома способами. На навігаційних вкладках (вікнах, кнопках) корисно вказувати стан тривоги, яка активна на відповідному дисплеї. Стандарт ISA-18.2 рекомендує, щоб інформація, задокументована під час раціоналізації тривог (така як причина, наслідки та дії оператора), була надана оператору [8].

Стадія впровадження передбачає проведення заходів пов’язаних з реалізацією окремих тривог чи всієї СТС, що безпосередньо завершує перехід до стадії експлуатації. Впровадження нових тривог чи нових СТС включає фізичну і логічну реалізацію і функціональну верифікацію системи. Оскільки оператори є невід'ємною частиною системи тривожної сигналізації, під час впровадження важливим етапом є навчання обслуговуючого персоналу та тестування нових тривог. Документація для навчання, тестування і введення в експлуатацію може відрізнятися в залежності від класу тривог. На етапі експлуатації тривоги або СТС є активними, і виконують свою функцію. Окрім того, що СТС перебуває безпосередньо в операційному стані, стандартом передбачається проведення підвищення кваліфікації персоналу з означеною періодичністю. Як правило, на конкретному підприємстві є певна програма проведення навчання, проте вона іноді ігнорується. На стадії технічного обслуговування, окрема тривога або СТС виводиться 3 експлуатації з метою перевірки, тестування або внесення змін до окремих атрибутів тривог. Для забезпечення ефективного функціонування СТС необхідно проводити періодичне тестування тривог відповідно до їх класу.

Ефективна організація роботи системи тривожної сигналізації потребує постійного вимірювання та розрахунку іiі ефективності з метою виявлення чинників, які перешкоджають справному функціонуванню. Тому що, навіть, у випадках, коли система розроблена згідно кращих практик, під час експлуатації можуть бути визначені незадовільні значення оцінюючих показників ефективності.

На стадії моніторингу та оцінювання роботи СТС, постійно контролюється загальна ефективність роботи СТС та окремих тривог з метою встановлення відповідності цілям, зазначеним у методології тривог. Моніторинг - це вимірювання кількісних показників. Оцінювання - це процес встановлення відповідності інформації отриманої завдяки моніторингу означеним цілям та показникам ефективності.

Передусім потрібно розуміти, що технології обробки даних та їх відображення дуже швидко розвиваються, але в той же час здатність людини (оператора) до осмислення, оцінювання та реагування не змінилася. Тому більшість показників ефективності покликані здебільшого оцінити здатність оператора обробити тривоги, а не здатність СТС генерувати їх. У попередній статті було розглянуто модель реагування оператора на тривогу [5]. Зважаючи на людський фактор, очевидно, що зі швидкістю виникнення тривог, яка становить 1 тривога в секунду впоратися неможливо. В таблиці 2 наведено основні показники ефективності роботи СТС, які обраховуються протягом експлуатації системи.

Таблиця 2 - Показники ефективності роботи СТС

\begin{tabular}{|c|c|c|}
\hline \multicolumn{3}{|c|}{$\begin{array}{c}\text { Показники ефективності роботи системи тривожної сигналізації (розраховуються на основі даних } \\
\text { зібраних якнайменше за } 30 \text { днів функціонування системи) }\end{array}$} \\
\hline Показник & \multicolumn{2}{|c|}{ Цільове значення } \\
\hline $\begin{array}{l}\text { К-сть сповіщень про тривогу за } \\
\text { конкретний проміжок часу на АРМ } \\
\text { оператора (швидкість виникнення } \\
\text { тривог) }\end{array}$ & Допустима кількість & Максимально допустима кількість \\
\hline За годину & 6 & 12 \\
\hline За 10 хвилин & 1 & 2 \\
\hline Показник & \multicolumn{2}{|c|}{ Цільове значення } \\
\hline $\begin{array}{l}\text { Відсоток } 10 \text {-хвилинних періодів, що } \\
\text { містять більше } 10 \text { тривог }\end{array}$ & \multicolumn{2}{|r|}{$\sim<1 \%$} \\
\hline $\begin{array}{l}\text { Максимальна кількість тривог за 10- } \\
\text { хвилинний період }\end{array}$ & \multicolumn{2}{|r|}{$<=10$} \\
\hline $\begin{array}{l}\text { Відсоток часу, під час якого система } \\
\text { перебуває у стані потоку тривог }\end{array}$ & \multicolumn{2}{|r|}{$\sim<1 \%$} \\
\hline $\begin{array}{l}\text { Відсоток топ } 10 \text { тривог, які часто } \\
\text { виникають в загальному навантажені } \\
\text { системи }\end{array}$ & \multicolumn{2}{|r|}{$\sim 1 \%$ до $5 \%$} \\
\hline Кількість повторюваних тривог & \multicolumn{2}{|r|}{0} \\
\hline Застарілі тривоги & \multicolumn{2}{|c|}{ менше 5 на поточний день, з планом дій для вирішення їх наявності } \\
\hline Розподіл пріоритетів & \multicolumn{2}{|c|}{$\begin{array}{c}3 \text { пріоритети: } \sim 80 \% \text { Low, } 15 \% \text { Medium, } \sim 5 \% \text { High } \\
4 \text { пріоритети: } \sim 80 \% \text { Low, } \sim 15 \% \text { Medium, } \sim 5 \% \text { High, }<1 \% \text { highest }\end{array}$} \\
\hline
\end{tabular}

Швидкість виникнення тривог відображає здатність систем керування підтримувати технологічний процес в межах, коли немає необхідності у втручанні оператора з метою уникнення наслідків. У разі пропущення тривоги, 
процес зазнає попередньо означених наслідків, якщо СТС добре спроектована. Під час розробки СТС дуже важливо враховувати сценарії поведінки персоналу, наприклад, якщо для вжиття коригувальних дій оператор повинен пройти велику відстань або у зв'язку з його обов'язками може із затримкою діагностувати тривогу.

Були проведені дослідження, які показали, що одна тривога за 10-хвилинний період в загальному може бути оброблена без значних наслідків для інших операційних обов'язків оператора. Проте швидкість більша за цю вже проблематична для нього. Візуалізацію такого показника рекомендується наводити у вигляді погодинних або денних графіків. Усереднені показники не завжди відображають реальні проблеми. Наприклад, аналіз може показати, що в попередньому місяці щоденно кількість тривог на добу сягала 120, тобто в середньому кількість тривог за 10хвилинний період становила 0,9. 3 першого погляду такий показник вказує на задовільну ефективність. Проте більш детальний аналіз може заперечувати це. Середня швидкість виникнення тривог може не вказувати на те, що було багато коротких періодів, коли швидкість виникнення тривог досягала 10 тривог за 10-хвилинний період, тобто періоди, коли ймовірно багато тривог було пропущено.

Аудит - це комплексна оцінка, яка включає оцінку ефективності підходів до процесу організації роботи СТС (наприклад, оцінка робочих процесів стадії керування змінами), які використовуються для адміністрування СТС. На стадії аудиту, проводяться періодичні перевірки з метою підтримки цілісності системи тривожної сигналізації і процесів організації функціонування тривог. Аудит ефективності системи може виявити прогалини, що не є очевидними при регулярному моніторингу. Він проводиться для того, щоб ідентифікувати необхідні внесення змін в систему для покращення ii роботи, наприклад в методологію тривог. Аудит повинен проводитись регулярно (рекомендується щорічно). Він повинен включати огляд документації, яка демонструє дотримання робочих процесів [9].

Моніторинг, оцінювання та аудит мають важливе значення для досягнення та задоволення цілей, які поставлені перед СТС стосовно іï ефективності. Діяльності означені стадіями моніторингу, оцінювання та аудиту дозволяють встановити можливості для вдосконалення СТС на інших стадіях ЖЦ.

На стадії керування змінами пропонуються і затверджуються зміни до системи тривожної сигналізації. При внесенні змін необхідно пройти всі стадії життєвого циклу від ідентифікації до впровадження. Можуть бути такі типи змін:

- тимчасові зміни тривог;

- тимчасові зміни параметрів (атрибутів) тривоги в поєднанні з розширеними та прогресивними методами;

• постійні зміни в головній базі даних тривог, атрибутів тривог та проектно-блокованих тривог.

Для забезпечення належної оцінки і затвердження змін, зроблених протягом розробки, впровадження, експлуатації чи обслуговування уповноваженими сторонами і їх документації, постійні зміни слідують відповідній процедурі керування змінами. Вона, як правило, включає задокументовану оцінку кожної зміни, записи системних модифікацій і авторизацію.

Слід наголосити на тому, що організація СТС - це неперервний процес, який триває 3 моменту виникнення ідеї створення системи до іï повного виводу з експлуатації. Підтримка системи після іï впровадження є дуже важливим етапом. На основі інформації отриманої завдяки моніторингу та аудиту тривоги можуть бути об’єктом робочих процесів інших етапів, при цьому залишаючись на стадії експлуатації.

\section{Висновки.}

Наше дослідження покликане сформувати у сучасного розробника стійке усвідомлення важливості забезпечити не лише гнучкий функціонал в межах якого будуть існувати тривоги, а й системно та комплексно підійти до питання створення СТС. Ми наголошуємо на системності, маючи на увазі необхідність прикладного застосування моделі життєвого циклу СТС. Кожна стадія освітлена у стандарті має своє вагоме значення і не повинна ігноруватися під час розроблення або функціонування системи. Часто ми зосереджуємося на робочих процесах стадії проектування, багато часу приділяємо графічному зображенню тих чи інших ненормальних умов, думаємо про кольори, прямокутники, шрифти, кількість сторінок з аварійними повідомленнями, виставляємо уставки, навіть, пам'ятаємо про зону нечутливості. Ці моменти неабияк важливі. Проте як довго ми думаємо про час необхідний оператору для вжиття коригувальних дій, про наслідки кожної тривоги, чи зважуємо кожну тривогу, дійсно вона нам потрібно або буде відволікати оператора. Етапи розроблення методології, ідентифікації та раціоналізації - це фундамент, який потрібно дуже добре викласти. Всі робочі процеси структуровані у формі життєвого циклу вимагають однакової уваги. До речі у формуванні стандарту було залучено дуже багато людей, величезна кількість документів проаналізовано, кожна стрілочка, форма та положення прямокутника в моделі життєвого циклу чітко продумані. Чому б цим не користуватися, коли від цього залежить безпека людей, якість продукції і як результат загальна продуктивність виробництва.

На сьогоднішній день існує багато SCADA-систем, вони відрізняються функціоналом, в одних його більше, а в інших зручніше використовувати. В будь-якому випадку слід обережно та обдумано використовувати запропонований інструментарій, тому що не все передбачене у SCADA необхідне. Також потрібно звертати увагу на термінологію, яка може омонімічно співпадати із стандартом, проте мати різне значення.

У статті достатньо лаконічно описано сутність життєвого циклу системи тривожної сигналізації для ознайомлення спільноти автоматників із стандартом 3 метою подальшого впровадження у своїй діяльності. Тому що ISA-18.2 покликаний забезпечити передусім безпеку. 
Список використаних джерел.

[1] Hollifield B., Alarm management handbook, 2nd ed., Pas, 2010.

[2] Mission. [Електронний pecypc] // Asmconsortium.net. - 2021. - Режим доступу до ресурсу: https://www.asmconsortium.net/defined/mission/Pages/default.aspx.

[3] EEMUA Publication 191 Digital. [Електронний pecypc] // Eemua.org. - 2021. - Режим доступу до ресурсу: https://www.eemua.org/Products/Publications/Digital/EEMUA-Publication-191.aspx.

[4] ANSI/ISA-18.2-2016. Management of Alarm Systems for the Process Industries. USA: ISA standards and Practices board, 2016.

[5] Пупена О. М., Шишак А. В. Сучасні стандарти з розроблення тривожної сигналізації в автоматизованих системах керування технологічними процесами. Автоматизація технологічних і бізнес-процесів, 2019. 11(3). c. 46-58.

[6] Пупена О.М. Розроблення людино-машинних інтерфейсів та систем збирання даних 3 використанням програмних засобів SCADA/НMI.: Навч. посіб. Київ : Видавництво Ліра-К, 2020. - 594 с.

[7] ISA-TR18.2.2-2016. Alarm Identification and Rationalization. USA: ISA standards and Practices board, 2016. c.42.

[8] ISA-TR18.2.3-2015. Basic Alarm Design. USA: ISA standards and Practices board, 2015. c.52.

[9] ISA-TR18.2.5-2012. Alarm System Monitoring, Assessment, and Auditing. USA: ISA standards and Practices board, 2012. c.68.

References.

[1] B. Hollifield, Alarm management handbook, 2nd ed., Pas, 2010.

[2] "Mission", $\quad 2021$. https://www.asmconsortium.net/defined/mission/Pages/default.aspx. [Accessed: 04- Jan- 2021]

[3] "EEMUA $\quad$ Publication $191 \quad$ Digital", $\quad$ Eemua.org, $2021 . \quad$ [Online]. Available: https://www.eemua.org/Products/Publications/Digital/EEMUA-Publication-191.aspx. [Accessed: 04- Jan- 2021].

[4] ANSI/ISA-18.2-2016, Management of Alarm Systems for the Process Industries, ISA standards and Practices board, 2016.

[5] O. Pupena and A. Shyshak, Modern standards of alarm management in process control systems, ATBP, vol 11, no 3, pp 46-58, Nov 2019.

[6] O. Pupena, Development of human-machine interfaces and data collection systems using SCADA/HMI software. Kyiv: Lira-K, 2020.

[7] ISA-TR18.2.2-2016, Alarm Identification and Rationalization, ISA standards and Practices board, 2016.

[8] ISA-TR18.2.3-2015, Basic Alarm Design, ISA standards and Practices board, 2015.

[9] ISA-TR18.2.5-2012, Alarm System Monitoring, Assessment, and Auditing, ISA standards and Practices board, 2012.

Отримана в редакції 05.01.2021. Прийнята до друку 22.02.2021. Received 05 January 2021. Approved 22 February

2021. Available in Internet 31 March 2021.

УДК 004.896:664.844.02

\section{АВТОМАТИЧНЕ КЕРУВАННЯ ПРОЦЕСОМ СУШНННЯ ПЛОДООВОЧЕВОЇ СИРОВИНИ В КОНДЕНСАЦІЙНІЙ ТЕРМОЕЛЕКТРИЧНІЙ СУШАРЦІ}

Якубаш I. В.

Одеська національна академія харчових технологій, м. Одеса, Україна

ORCID: 0000-0002-2260-410X

E-mail: jakubash@ukr.net

Copyright (C) 2021 by author and the journal “Automation of technological and business - processes”.

This work is licensed under the Creative Commons Attribution International License (CC BY).

http://creativecommons.org/licanses/by/4.0

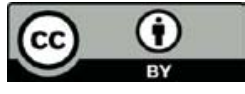

ONAFT

Open Access

DOI:

Анотація. Сушіння є одним з найбільи ефективних методів збереження сільськогосподарських $i$ харчових продуктів. Якість висушеного продукту залежить від дотримання регламенту технологічного процесу сушіння. 